\title{
PERBANDINGAN HASIL BELAJAR FISIKA ANTARA METODE PICTORIAL RIDDLE DAN METODE DEMONSTRASI DALAM PEMBELAJARAN INQUIRY TERBIMBING PADA SISWA KELAS VIII SMP NEGERI 19 PALU
}

\author{
Susilawati ${ }^{1}$, Fihrin ${ }^{2}$ dan I Wayan Darmadi \\ Email: susilawatifis@yahoo.com \\ Program Studi Pendidikan Fisika, Jurusan Pendidikan MIPA, Universitas Tadulako \\ Jl. Soekarno Hatta KM. 9 Kampus Bumi Tadulako Tondo Palu - Sulawesi Tengah
}

\begin{abstract}
Abstrak - Telah dilakukan penelitian dengan tujuan untuk mengetahui ada tidaknya perbedaan hasil belajar fisika antara siswa yang mengikuti pembelajaran inquiry terbimbing dengan metode pictorial riddle dan siswa yang mengikuti pembelajaran inquiry terbimbing dengan metode demonstrasi. Penelitian ini merupakan penelitian eksperimen kuasi dengan rancangan Pretest-Posttest Comparison Group Design. Populasi dalam penelitian ini adalah seluruh siswa kelas VIII SMP Negeri 19 Palu. Sampel penelitian adalah kelas VIII B sebagai kelompok eksperimen A dengan jumlah siswa 20 orang dan kelas VIII C sebagai kelompok eksperimen B dengan jumlah siswa 20 orang. Hasil belajar yang diperoleh menunjukkan bahwa nilai rata-rata kelompok eksperimen A mencapai skor 10,5 dan kelompok eksperimen B mencapai skor 9,1. Berdasarkan hasil pengujian hipotesis, diperoleh thitung $=1,54$ dan tabel $=2,02$ pada taraf nyata $\alpha=0,05$ dengan kriteria penerimaan, Ho diterima jika $\left.-\mathrm{t}_{(1-0.5} \alpha\right)<\mathrm{t}<\mathrm{t}_{(1-}$ $0.5 \alpha$ ) dan tolak Ho dalam hal lain. Demikian, karena thitung < tabel maka artinya Ho diterima. Berdasarkan hasil uji hipotesis tersebut maka dapat disimpulkan bahwa tidak terdapat perbedaan hasil belajar antara siswa yang mengikuti pembelajaran inquiry terbimbing dengan metode pictorial riddle dan siswa yang mengikuti pembelajaran inquiry terbimbing dengan metode demonstrasi.
\end{abstract}

Kata Kunci: Metode Pictorial Riddle; Metode Demonstrasi; Hasil Belajar

\section{PENDAHULUAN}

Belajar merupakan salah satu proses yang harus ditempuh dalam pendidikan. Belajar merupakan kegiatan aktif dalam membangun makna dan pemahaman. Dengan demikian, guru perlu memberikan dorongan kepada siswa untuk membangun otoritas dalam membangun gagasan.

Fisika sebagai salah satu dari Ilmu Pengetahuan Alam (IPA) merupakan objek mata pelajaran yang menarik dan lebih banyak memerlukan pemahaman dari pada penghafalan. Namun, kenyataannya siswa sering beranggapan bahwa fisika merupakan pelajaran yang sulit dan kurang menarik. Hal ini dikarenakan dalam mata pelajaran fisika banyak menggunakan rumus sehingga dalam menyelesaikan suatu masalah fisika mereka bingung untuk memilih rumus mana yang harus digunakan.
Dalam dunia pendidikan saat ini, telah banyak dikenal pendekatan dan model-model pembelajaran yang bertujuan untuk menumbuhkan ketertarikan siswa untuk mempelajari fisika. Salah satunya adalah pembelajaran inquiry terbimbing. Pembelajaran inquiry merupakan kegiatan pembelajaran yang melibatkan secara maksimal seluruh kemampuan siswa untuk mencari dan menyelidiki sesuatu (benda, manusia atau peristiwa) secara sistematis, kritis, logis, analitis sehingga mereka dapat merumuskan sendiri penemuannya dengan penuh percaya diri. Pembelajaran inquiry merupakan proses pembelajaran yang lebih menekankan peran aktif mahasiswa baik fisik maupun mental dalam menemukan suatu konsep [1].

Pembelajaran inkuiri terbimbing (Guided inquiry) yaitu suatu model pembelajaran inkuiri yang dalam pelaksanaannya guru menyediakan bimbingan atau petunjuk cukup luas kepada 


\section{Jurnal Pendidikan Fisika Tadulako (JPFT)}

Vol. 1 No.3

ISSN 23383240

siswa. Sebagian perencanaannya dibuat oleh guru, siswa tidak merumuskan problem atau masalah. Dalam pembelajaran inkuiri terbimbing guru tidak melepas begitu saja kegiatan-kegiatan yang dilakukan oleh siswa [2].

Adapun langkah-langkah dalam melaksanakan pembelajaran inquiry adalah sebagai berikut.

1) Orientasi

2) Merumuskan masalah

3) Merumuskan hipotesis

4) Mengumpulkan data

5) Menguji hipotesis

6) Merumuskan kesimpulan [3].

Cara lain untuk menarik minat siswa dalam mempelajari fisika adalah dengan gambar. Salah satu metode pembelajaran yang menggunakan gambar sebagai bentuk penyajian masalah adalah metode pictorial riddle. Metode pictorial riddle adalah metode untuk mengembangkan aktivitas siswa dalam didkusi kelompok kecil maupun besar, melalui penyajian masalah yang disajikan dalam bentuk ilustrasi. Suatu riddle biasanya berupa gambar, baik di papan tulis, papan poster maupun diproyeksikan dalam bentuk transparansi, kemudian guru mengajukan pertanyaan yang berkaitan dengan riddle tersebut. Suatu riddle biasanya berupa gambar di papan tulis, papan poster atau diproyeksikan dari suatu transparansi, kemudian guru mengajukan pertanyaan-pertanyaan berkaitan dengan riddle [4].

Selain dengan gambar, dengan memperlihatkan atau memperagakan suatu proses atau peristiwa secara sistematis dapat memberikan pengalaman belajar yang menyenangkan untuk siswa. Metode yang memperagakan suatu proses untuk memperoleh pengetahuan yaitu metode demonstrasi. Metode demonstrasi adalah cara mengajar dimana seseorang instruktur/guru menunjukkan, memperlihatkan suatu proses sehingga seluruh siswa dalam kelas dapat melihat, mengamati, mendengar dan merasakan proses yang ditunjukkan oleh guru tersebut [5].

Berdasarkan hal tersebut, peneliti ingin membandingkan hasil belajar fisika antara siswa yang memperoleh suatu pengetahuan hanya dengan melihat gambar dan dengan melihat prosesnya (peragaan). Untuk itu, peneliti ingin melakukan penelitian dengan judul
"Perbandingan Hasil Belajar Fisika Siswa Antara Metode Pictorial Riddle Dan Metode Demonstrasi Dalam Pembelajaran Inquiry Terbimbing Pada Siswa Kelas VIII SMP Negeri 19 Palu".

\section{METODOLOGI}

Jenis penelitian yang digunakan pada penelitian ini adalah adalah jenis penelitian eksperimen kuasi (quasi experimental designs).Pada penelitian ini digunakan 2 kelas sebagai sampel. Adapun desain penelitian yang digunakan adalah sebagai berikut.

Tabel 1. Pretest-Posttest Comparison Group Design (Desain Kelompok Pembanding Prates-pascates)

\begin{tabular}{cccc}
\hline Kelompok & Prates & Perlakuan & Pascates \\
\hline A (KE) & $\mathrm{O}$ & $X_{A}$ & 0 \\
B (KE) & $\mathrm{O}$ & $X_{B}$ & $\mathrm{O}$ \\
\hline
\end{tabular}

Keterangan:

$X_{A}$ : Perlakuan untuk kelas eksperimen dengan menggunakan pembelajaran inquiry terbimbing dengan metode pictorial riddle.

$X_{B}$ : Perlakuan untuk kelas eksperimen dengan menggunakan pembelajaran inquiry terbimbing dengan metode demonstrasi.

Sampel dipilih dua kelas dengan cara purposive sampling yaitu teknik pengambilan sampel berdasarkan pertimbangan tertentu. Dalam hal ini pertimbangan berdasarkan rekomendasi dari guru mata pelajaran fisika di sekolah tersebut. Adapun populasi pada penelitian ini adalah seluruh siswa kelas VIII SMP Negeri 19 Palu yang terdaftar dalam tahun ajaran 2013/2014 tersebar dalam 6 kelas.

\section{HASIL DAN PEMBAHASAN}

\section{Data Hasil Belajar}

Data hasil belajar fisika siswa dari pretest dan posttest yang dilakukan pada kedua kelas baik eksperimen A dengan jumlah siswa 20 orang dan kelas eksperimen $B$ dengan jumlah siswa 20 orang dapat dilihat pada tabel 2 . 
Tabel 2. Skor pretest dan posttest kelas eksperimen A dan kelas eksperimen $B$

\begin{tabular}{lcccc} 
& \multicolumn{2}{c}{ Kelas } & \multicolumn{2}{c}{ Kelas } \\
\multirow{2}{*}{ Skor } & \multicolumn{2}{c}{ Eksperimen A } & \multicolumn{2}{c}{ Eksperimen B } \\
\cline { 2 - 5 } & $\begin{array}{c}\text { Pretes } \\
t\end{array}$ & $\begin{array}{c}\text { posttes } \\
t\end{array}$ & $\begin{array}{c}\text { Pretes } \\
t\end{array}$ & $\begin{array}{c}\text { posttes } \\
t\end{array}$ \\
\hline $\begin{array}{l}\text { Maksimu } \\
\text { m }\end{array}$ & 17 & 17 & 17 & 17 \\
\hline Tertinggi & 9 & 16 & 9 & 15 \\
\hline Terendah & 2 & 6 & 1 & 5 \\
\hline $\begin{array}{l}\text { Rata- } \\
\text { Rata }\end{array}$ & 5,5 & 10,5 & 5,9 & 9,1 \\
\hline
\end{tabular}

2. Analisis Data Pretest

Analisis data pretest digunakan untuk mengetahui kemampuan awal siswa sebelum mengikuti pembelajaran. Untuk mengetahui kemampuan awal siswa, sama atau berbeda peneliti melakukan uji homogenitas.

a) Uji Homogenitas

Untuk melakukan uji homogenitas menggunakan uji statistik Fisher (uji F) dengan taraf signifikansi $a=0,05$. Hal ini dilakukan untuk melihat apakah data berasal dari variansi yang sama atau tidak. Dari pengolahan data pretest diperoleh nilai $F_{\text {hitung }}=1,23$ dan $F_{\text {tabel }}=2,12$. Berdasarkan hasil tersebut terlihat bahwa $F_{\text {hitung }}<F_{\text {tabel }}$ sehingga dapat disimpulkan bahwa kedua data berasal dari variansi yang sama (homogen).

3) Analisis Data Posttest

a) Uji Normalitas

Untuk menguji data hasil belajar fisika tersebut terdistribusi normal atau tidak maka digunakan persamaan chi kuadrat. Hasil normalitas data kelompok eksperimen A diperoleh hasil yaitu $X^{2}$ hit $=1,02$ dan $X^{2}$ tab ( $d K$ $=2, a=0,05)=7,81$. Kemudian Pengujian normalitas data kelompok eksperimen B diperoleh hasil yaitu $X^{2}$ hit $=1,89$ dan $X^{2}$ tab ( $d k$ $=2, \alpha=0,05)=5,99$. Dengan membandingkan harga $\mathrm{X}^{2}$ hit dengan harga $\mathrm{X}^{2}$ tab tampak bahwa baik kelas eksperimen $A$ maupun kelas eksperimen $B$ diperoleh $X^{2}$ hit $<X^{2}$ tab. Hal ini berarti bahwa data kelompok eksperimen $B$ berdistribusi normal.

b) Uji Homogenitas

Untuk melakukan uji homogenitas menggunakan uji statistik Fisher (uji F) dengan taraf signifikansi $a=0,05$. Hal ini dilakukan untuk melihat apakah data berasal dari variansi yang sama atau tidak. Dari pengolahan data
ISSN 23383240

pretest diperoleh nilai $F_{\text {hitung }}=1,10$ dan $F_{\text {tabel }}=2,12$. Berdasarkan hasil tersebut terlihat bahwa $F_{\text {hitung }}<F_{\text {tabel }}$ sehingga dapat disimpulkan bahwa kedua data berasal dari variansi yang sama (homogen).

c) Uji Hipotesis

Pengujian hipotesis ini menggunakan uji kesamaan dua rata-rata (uji dua pihak). Kriteria penerimaan yakni terima $\mathrm{H}_{0}$ jika $-\mathrm{t}_{(1-1 / 2}$ a) $<\mathrm{t}<$ $\mathrm{t}_{(1-1 / 2 \mathrm{a})}$ dengan taraf nyata $\mathrm{a}=0,05 \mathrm{dan} \mathrm{dk}=$ $\mathrm{n}_{1}+\mathrm{n}_{2}-2=20+20-2=38$ dan untuk harga $\mathrm{t}$ lainnya $\mathrm{H}_{1}$ diterima. Dari daftar tabel distribusi $t$ diperoleh harga $\operatorname{tab}_{\operatorname{ta}(0,975)(38)}=2,02$ sedangkan thit $=1,54$. Hal ini berarti harga thit berada di dalam daerah penerimaan $\mathrm{H}_{0}$ shingga $\mathrm{H}_{1}$ di tolak pada taraf nyata $\mathrm{a}=0,05$. Dengan demikian dapat disimpulkan bahwa tidak terdapat perbedaan hasil belajar físika antara kedua kedua kelas baik kelas eksperimen $A$ maupun kelas eksperimen $B$.

Penelitian ini bertujuan untuk mengetahui ada tidaknya perbedaan hasil belajar fisika siswa yang mengikuti pembelajaran inquiry terbimbing dengan metode pictorial riddle dan siswa yang mengikuti pembelajaran inquiry terbimbing dengan metode demonstrasi.

Analisis data pretest (prates) bertujuan untuk melihat kemampuan awal siswa tentang Hukum-Hukum Newton pada kedua kelas eksperimen sebelum diberikan treatment pembelajaran inquiry terbimbing dengan metode pictorial riddle dan pembelajaran inquiry terbimbing dengan metode demonstrasi. Setelah dilakukan analisis uji homogenitas diperoleh data memiliki varians yang homogen. Hasil ini membuktikan bahwa kemampuan awal kedua kelas yang dijadikan sebagai sampel penelitian adalah sama.

Analisis data posttest bertujuan untuk mengetahui ada tidaknya perbedaan hasil belajar fisika mengenai materi Hukum-Hukum Newton antara siswa yang telah mengikuti pembelajaran inquiry terbimbing dengan metode pictorial riddle dan siswa yang telah mengikuti pembelajaran inquiry terbimbing dengan metode demonstrasi. Pertama-tama data hasil belajar siswa dihitung uji normalitasnya. Apabila data terdistribusi normal maka mengujian dilanjutkan pada uji homogenitas dan apabila data tersebut homogen maka dilanjutkan pada uji hipotesis. Pada pengujian normalitas data kelas 


\section{Jurnal Pendidikan Fisika Tadulako (JPFT)}

Vol. 1 No. 3

ISSN 23383240

eksperimen A dan kelas eksperimen B diperoleh bahwa kedua data terdistribusi normal. Hasil uji homogenitas pada kedua data adalah varians kedua kelompok homogen. Pada uji hipotesis diperoleh bahwa $\mathrm{H}_{0}$ diterima dan $\mathrm{H}_{1}$ ditolak. Artinya tidak terdapat perbedaan hasil belajar fisika antara siswa yang mengikuti pembelajaran inquiry terbimbing dengan metode pictorial riddle dan siswa yang mengikuti pembelajaran inquiry terbimbing dengan metode demonstrasi.

Hasil ini diperoleh kemungkinan disebabkan oleh beberapa hal. Pertama siswa diajak dalam suatu permasalahan yang berhubungan dengan kehidupan sehari-hari sehingga menimbulkan ketertarikan siswa. Kedua, pada pelaksanaan pembelajaran, ada beberapa langkah pembelajaran yang sama antara pembelajaran inquiry terbimbing dengan metode pictorial riddle dan inquiry terbimbing dengan metode demonstrasi yaitu pada fase menyusun hipotesis, dimana siswa didorong oleh guru untuk merumuskan hipotesis dengan memberikan pertanyaan-pertanyaan yang berhubungan dengan permasalahan yang telah disampaikan sebelumnya. Pada fase ini, siswa diberikan kebebasan untuk menentukan hipotesisnya sendiri yang relevan dengan materi yang sedang dipelajari sehingga dapat meningkatkan cara berpikir kritis siswa. Kemudian pada fase mengumpulkan dan menganalisis data. Fase ini merupakan proses mencari jawaban atas permasalahan yang telah dikemukakan sebelumnya. Kegiatan yang dilakukan pada fase ini adalah berdiskusi. Melalui proses tersebut siswa akan memperoleh pengalaman yang sangat berharga sebagai upaya mengembangkan mental melalui proses berpikir. Selanjutnya pada fase merumuskan kesimpulan. Pada fase ini, siswa mendeskripsikan temuan yang diperoleh berdasarkan data yang ada sehingga memudahkan siswa dalam memahami konsep suatu materi dan dapat menerapkannya dalam kehidupan sehari-hari.

Adapun kelemahan dari penelitian ini adalah kurangnya observasi sebelum melakukan penelitian. Sehingga kemungkinan hasil yang diperoleh tidak sesuai dengan yang diharapkan. Kelebihan menggunakan kedua metode pembelajaran ini membuat siswa dapat meningkatkan motivasi belajarnya karena pada pembelajaran ini mereka dilibatkan secara aktif dalam proses pembelajaran. Hal ini ditunjukkan dengan penelitian-penelitian yang telah dilakukan sebelumnya.

Penelitian yang dilakukan oleh Alfriska menunjukkan bahwa penggunaan pembelajaran scientific inquiry berbasis pictorial riddle dapat meningkatkan hasil belajar bila aktivitas belajar siswa ditingkatkan. Selain itu, penelitian yang dilakukan Dewi Amelia menunjukkan bahwa penerapan model pembelajaran inkuiri dengan metode pictorial riddle dapat meningkatkan pemahaman konsep pemantulan cahaya pada siswa kelas VIII. Hasil penelitian yang dilakukan oleh kristianingsih juga menunjukkan bahwa model pembelajaran inkuiri dengan metode pictorial riddle dapat meningkatkan hasil belajar siswa SMK.

Penelitian yang dilakukan oleh Dedi Rohendi menjelaskan bahwa metode pembelajaran demonstrasi sangat efektif dalam meningkatkan hasil belajara siswa SMK. Selain itu, penelitian yang dilakukan oleh Rubiyono juga menunjukkan bahwa penggunaan metode pembelajaran demonstrasi dapat meningkatkan hasil belajar siswa.

\section{KESIMPULAN DAN SARAN}

Berdasarkan hasil penelitian dapat disimpulkan bahwa tidak terdapat perbedaan hasil belajar fisika antara metode pictorial riddle dan metode demonstrasi dalam pembelajaran inquiry terbimbing pada siswa kelas VIII SMP Negeri 19 Palu.

Adapun saran yang dapat penulis berikan bagi peneliti selanjutnya yang akan meneliti dengan menggunakan model dan metode pembelajaran yang sama hendaknya mampu mengelola waktu. Hal ini dikarenakan dalam pelaksanaannya memerlukan waktu yang lama agar pembelajaran berlangsung dengan lancar.

\section{DAFTAR RUJUKAN}

[1] Handhika, J. (2010). "Pembelajaran Fisika melalui Inquiry Terbimbing dengan Metode Eksperimen dan Demonstrasi Ditinjau dari Aktivitas dan Perhatian Mahasiswa". Jurnal Penelitian Pendidikan Fisika, Vol 1 (1), 9-23.

[2] Andriani Nely. 2011. Efektifitas Penerapan Inkuir Terbimbing (GuidedInquiry)Pada Mata Pelajaran Fisika Pokok Bahasan Cahaya Di Kelas VIII SMP Negeri 2 


\section{Jurnal Pendidikan Fisika Tadulako (JPFT)}

Vol. 1 No.3

ISSN 23383240

Muara Padang. Prosiding Simposium Nasional. Bandung.

Pembelajaran Inquiry dengan Metode Pictorial riddle pada Pokok Bahasan Alat-Alat Optik di SMP". Jurnal Pendidikan Fisika Indonesia. Jurnal Pendidikan Fisika Indonesia, Vol 6, 10-13.

[3] Sanjaya W. (2008). Strategi Pembelajaran Berorientasi Standar Proses Pendidikan. Kencana Prenada Media Group. Jakarta.

[5] Roestiyah. 1991. Strategi Belajar dan Pembelajaran. P.T. Rineka Cipta. Jakarta.

[4] Khanafiyah, S., Kristianingsih, D, D., \& Sukiswa. 2010.

"Peningkatan Hasil Belajar Siswa melalui Model 